\begin{tabular}{|c|c|c|c|}
\hline \multirow{2}{*}{$\begin{array}{c}\text { LARUS } \\
\text { Hrvatska akademija } \\
\text { znanosti i umjetnosti }\end{array}$} & 53 & $\begin{array}{c}\text { 7-18 str. } \\
\text { 2 tablice, } 3 \text { slike }\end{array}$ & Zagreb 2018 \\
\cline { 2 - 4 } & $(2018)$ & \multicolumn{3}{|c|}{ Primljeno 11.4.2018. } \\
\cline { 2 - 4 } & Prihvaćeno na sjednici Razreda za prirodne znanosti HAZU 9.10.2018. \\
\hline
\end{tabular}

UDK 598.279.31(497.521.2)

Original scientific paper Izvorni znanstveni članak DOI: https://dx.doi.org/10.21857/y6zolb8o3m

\title{
HABITAT PREFERENCES OF COMMON KESTREL Falco tinnunculus IN ZAGREB
}

\author{
Izbor staništa vjetruše Falco tinnunculus u Zagrebu \\ VikTORIa Kolarić \\ Jakova Gotovca 30, HR-31400 Đakovo, Croatia
}

\begin{abstract}
Common Kestrel Falco tinnunculus is a bird of prey that colonized European cities most successfully. It is a resident bird in Zagreb, nesting in the centre of the city. The main purpose of this study was to locate and analyse the positions of active nests of Common Kestrels during the breeding season of 2017 in Zagreb. "The Atlas of breeding birds of Zagreb" was used as the basis of knowledge about the distribution of Kestrels in Zagreb. After the field research, the characteristics of nesting sites were analysed; subsequently - by using GIS program - the distances between nesting sites and nearest urban green areas that are used for foraging were measured. This study gave insight into the habitat preferences for the nesting of Kestrels in Zagreb. It has been shown that the most suitable buildings for the nesting of Kestrels in Zagreb are residential buildings with an average height of 50.1 meters. Beside smaller urban green areas, large green areas outside the city centre were also of great importance, with the embankment of the Sava river proved to be the most significant one.
\end{abstract}

Keywords: Falco tinnunculus, birds of prey, nest, nesting, urban areas

\section{INTRODUCTION}

Urban areas are nowadays becoming more and more widespread. Urbanization is considered one of the most important factors responsible for the decrease of biodiversity and the homogenization of environments (ЈокімёкI et al. 2016). Increased urbanization usually leads to an increase in biomass of birds, but also

e-mail: viktoriakolaric@gmail.com 
to a decrease in species diversity (CHAcE \& Walsh 2004). Domination of some bird species and low level of diversity can lead to homogenisation in bird communities. It has been shown that the number of breeding bird species in urban core zones of European cities is approximately $20 \%$ of the total number of European breeding bird species (Jокімёкі et al. 2016). One of the factors that have an effect on bird species diversity in urban areas is disturbance caused by human activities, although it is been shown that some bird species are still capable to successfully colonise urban environment (Jокімёкі et al. 2016). Although urbanisation reduces the diversity of animal species by destroying natural habitats, to a lesser extent it also creates new habitats for some species (CHARTER et al. 2007). Bird species often depend on vegetation structure. Therefore, some native bird species inhabit urban areas, which, despite important habitat changes, keep the native vegetation. For some birds, urban areas provide rich food supplies, either directly (at bird feeders) or indirectly - in areas of waste treatment, collection and transfer (CHACE \& Walsh 2004).

Urban habitats can be of superior quality for some raptor species, because in these habitats raptors are often free from persecution, and may have an adequate food supply. This may encourage raptors to inhabit some, usually unsuitable, nesting sites. Many species of raptors have taken advantage of artificial nesting sites, which can sometimes lead to a greater reproductive success than on wild sites (Chace \& Walsh 2004). Many species of falcons respond well to urban habitats because of the greater biomass of small birds (CHACE \& WALSH 2004). Some studies have also shown that some raptor species have changed their diet habits after moving from agricultural habitats (where they usually feed on rodents) to urban areas (where they feed on passerine birds) (SorAce 2001).

Common Kestrel breeds throughout much of Europe, Africa and Asia (VILLAGE 1990). Compared to other birds of prey, it has successfully colonised cities. This is shown through higher breeding densities in cities than in farmland populations (RIEGERT et al. 2007). As permanently changing the ecosystem, urban areas suffer from decreasing biodiversity, and now they are characterized by lower proportions of green space and the conversion of original vegetation or farmlands to parklands and backyards (SumASGUTNER et al. 2014). The main part of Kestrels diet being rodents, they are forced to hunt them outside the urban centres. This is why one of the most important factors for successful nesting is short distance from nesting sites to open green areas (RIEGERT et al. 2007). The availability of suitable nesting sites in urban areas can be a limiting factor for Kestrels breeding occurrence, although it is known that any kind of building that provides protection and can hold eggs is a potential nesting site for Kestrels (Sumasgutner et al. 2014). On the other hand, studies have shown that Kestrels breeding in urban habitats use different types of nests and prey on more bird species than those breeding in rural habitats, which leads to higher reproduction 
level of urban pairs (CHARTER et al. 2007). Urban populations of Kestrels showed genetic and behavioural differences compared to Kestrels from rural habitats (Sumasgutner et al. 2014).

Common Kestrel is a numerous and widespread breeding species in Croatia. The breeding population was estimated to around 9,000 - 10,000 pairs (KRALJ et al. 2013). Common Kestrel is a resident bird in Zagreb, nesting even in the centre of the city. Studies on urban Kestrels have been conducted in few European cities (KüBler et al. 2005, Sumasgutner et al. 2014, Riegert et al. 2007, Salvati et al. 1999, SoraCe 2001), but not in Croatia. The main purpose of this study was to locate the positions of active nests of Common Kestrel during the breeding season of 2017 in Zagreb and analyse the habitat preference of urban Kestrel population.

\section{MATERIAL AND METHODS}

The analysis of Common Kestrel habitat has been conducted in Zagreb, Croatia $\left(45^{\circ} 49^{\prime} \mathrm{N}, 15^{\circ} 59^{\prime} \mathrm{E}\right)$. Zagreb situated in the northwest part of Croatia, on the slopes of the Medvednica mountain along the Sava river (DEPARTMENT OF APPLIED computing, Official website 2017). The climate in Zagreb is of continental type, the summers are hot and dry, with an average temperature around $21^{\circ} \mathrm{C}$, and winters are cold, with an average temperature around $1^{\circ} \mathrm{C}$. In the spring of 2017, when the study was conducted, maximum and minimum temperatures were as follows: March $23^{\circ} \mathrm{C} /-2^{\circ} \mathrm{C}$, April $25^{\circ} \mathrm{C} /-1^{\circ} \mathrm{C}$, May $31^{\circ} \mathrm{C} / 7^{\circ} \mathrm{C}$, and the first half of June $31^{\circ} \mathrm{C} / 9^{\circ} \mathrm{C}$ (Accu Weather 2017). The surface area of Zagreb is $641.355 \mathrm{~km}^{2}$, and the population was 790,017 in 2011 (Сity of Zagreb, Official website 2017).

"The Atlas of breeding birds of Zagreb" (Kralj \& KRnjeTA 2015) was used as the basis of knowledge about the distribution of Common Kestrel in Zagreb. For the purpose of the breeding bird survey, Zagreb area was divided into a $1 \times 1 \mathrm{~km}$ grid. The city was thereby divided into a total of 161 squares, of which 88 were surveyed quantitatively. The presence of Common Kestrel was recorded on a total of 37 squares, and the breeding population was estimated to 45-50 pairs. As the Atlas survey was undertaken in the period from 2003 to 2015, the latest data of currently active nests had to be collected, and the list of new locations completed.

Field research was conducted in the period from the end of March to early June 2017, at the time of the highest activity of Kestrels, when they may easily be spotted thanks to loud calls and frequent flythrough in search for food. This research was concentrated on the central, urban part of the city. Therefore, from 37 squares with the recorded nesting of Kestrels, this study was carried out on the initial 28 squares. The study included a survey of previously known locations, on which nesting of Kestrels had been recorded by KraLj \& KRnJeTA (2015), but also on three new locations, on which nesting of Kestrels was recorded in the past 
two years by ornithologists, colleagues, and citizens of Zagreb. After the activity of Kestrels had been spotted, the locations of nests were located by observing the birds. Once a nest was located, for each nest type and height of the building and presence of higher buildings in the surrounding area were recorded. For two sites where the pair was active, but the nest has not been located, average height and type of surrounding buildings that might potentially serve as the nesting site were taken. In the analysis of habitat, besides the currently active nests, the locations of five previously known nests were included in order to achieve better coverage of the studied area.

During this study, the hunting activity of Kestrels was recorded on green areas around the nesting sites, and on larger green areas that are more distant from the recorded nests; thus, the characteristics of the used green areas were analysed. For the purpose of this analysis, the QGIS program was used (QGIS Development Team 2017). Using QGIS application (Version 2.18.14.), the Google Maps (Google Satellite) layer has been uploaded via Open Layers plug-in. According to the data collected during field research in the Zagreb area using the Measure Area function, the size of green areas, where the activity of the Kestrels has been recorded, have been measured. Furthermore, using Measure Line function, the air distances between each nest location and nearest urban green areas have been measured. After the analysis, the urban green areas that had been used were divided by size into four categories:

1 Green areas up to 5 hectares

2 Green areas from 5 to 50 hectares

3 Green areas from 50 to 100 hectares

4 Green areas larger than 100 hectares

The fourth category includes all large green urban areas (over 100 ha: Sava river embankment, Jarun, Bundek, Grmoščica, Tuškanac, Maksimir).

Using the QGIS application, a view of the analysed locations has been made by uploading the coordinates of locations in the form of Comma Delimited file. For better visibility, the locations have been displayed on the Bing Maps (Bing Road) layer uploaded via Open Layers plug-in.

\section{RESULTS}

\section{Nesting locations included in the analysis}

After field research conducted on a total of 32 atlas squares, the activity of Kestrels was recorded on a total of 13 squares, out of which on 11, nesting locations were recorded; whereas on 2 squares, the activity of Kestrels was recorded, but the location of the nest has not been specified. Out of the 13 confirmed squares, nesting was recorded on 3 new squares compared to former studies, and activi- 
ties without specified nest location were recorded on one new square. Besides the locations on which Kestrels activities were recorded in the breeding season of 2017, additional 5 locations of once active nests were also included in the analysis of nesting sites (Figure 1), giving the total of 18 nests included in the analysis.

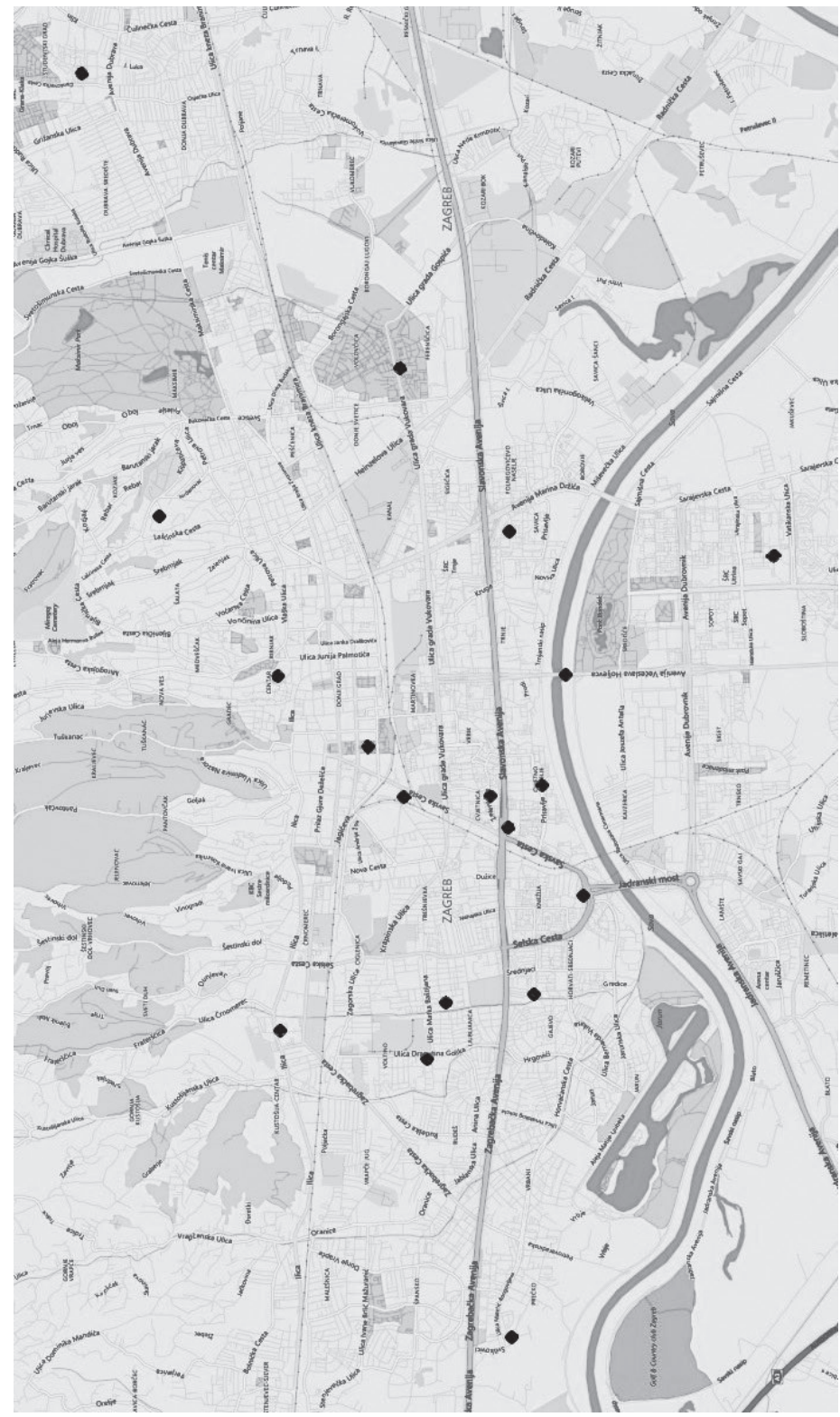

Figure 1. Nesting locations of Common Kestrel that have been analysed.

Slika 1. Položaj analiziranih lokacija gniježđenja vjetruše. 


\section{Characteristics of nesting sites}

The average height of the buildings, on which Kestrels were nesting, was 50.1 $\pm 26.1 \mathrm{~m}$. The highest building, on which nesting of Kestrels was recorded, is the Zagreb cathedral, which is $105 \mathrm{~m}$ high. The majority of nests were located on buildings between 25 and $70 \mathrm{~m}$ high. Table 1 shows the height and type of the buildings on which nests were located. Out of the 18 nest locations, on 7 (39\%) locations higher buildings were found within a $500 \mathrm{~m}$ radius around the building chosen for nesting. On the remaining 11 (61\%) locations, the building that was chosen for nesting was the highest in the neighbourhood.

Table 1. Height and type of buildings where nesting of Common Kestrel was recorded.

Tablica 1. Visine i tip građevina na kojima je zabilježeno gniježđenje vjetruše.

\begin{tabular}{|c|c|c|c|c|}
\hline & Location & Square & $\begin{array}{l}\text { Height of } \\
\text { the building } \\
\text { (m) }\end{array}$ & Type of the building \\
\hline 1. & Jordanovac - Dobri dol & G14 & 30 & Residential building \\
\hline 2. & Dubrava - Dankovečka & G19 & 60 & Residential building \\
\hline 3. & Črnomerec - Gjure Szaba & 19 & 18 & Residential building \\
\hline 4. & Trg bana Jelačića - Katedrala & 113 & 105 & Church tower \\
\hline 5. & Voltino - Dragutina Golika & J9 & 50 & Residential building \\
\hline 6. & Remiza - Jablanovečka ulica & $\mathrm{J} 10$ & 58 & Residential building \\
\hline 7. & Trešnjevka - Cibonin toranj & $\mathrm{J} 12$ & 92 & Business building \\
\hline 8. & Marulićev trg & $J 12$ & 25 & Business building \\
\hline 9. & Ferenšćica & $J 16$ & 30 & Residential building \\
\hline 10. & Prečko - Paljetkova ulica & K6 & 25 & Residential building \\
\hline 11. & Srednjaci & K10 & 73 & Residential building \\
\hline 12. & Knežija - Vjesnik & K11 & 67 & Business building \\
\hline 13. & Vrbik - Prisavlje & K12 & 73 & Residential building \\
\hline 14. & Zeleni trg & K12 & 70 & Residential building \\
\hline 15. & Most Slobode & K13 & 15 & Lightning pole \\
\hline 16. & Trnje - Lastovska & K14 & 40 & Residential building \\
\hline 17. & Knežija - Horvaćanska & L10 & 35 & Residential building \\
\hline 18. & Travno - Božidara Magovca & M14 & 35 & Residential building \\
\hline
\end{tabular}




\section{The nesting location in relation to urban green areas}

In Table 2, the air distances of analysed locations to the nearest green area from each category have been presented. Eleven nests were situated within urban green areas (Figure 2).

The most of the nests were located within category 2 (from 5 to 50 ha), while there were no nests inside category 3 (from 50 to 100 ha). Nests that were not located within one of the categories of green areas were on an average distance of $222.8( \pm 204.3) \mathrm{m}$ from the nearest green area.

Figure 3 shows the number of the nests to the nearest green area from category 4 . For the largest number of nests (50\%), the nearest large green area was the embankment of the Sava river.

Table 2. Distances between nesting locations and green areas.

Tablica 2. Udaljenosti lokacija gniježđenja od zelenih površina.

\begin{tabular}{|c|c|c|c|c|c|}
\hline \multirow[b]{2}{*}{ Location } & \multirow[b]{2}{*}{ Square } & \multicolumn{4}{|c|}{$\begin{array}{c}\text { Distances between nesting locations and } \\
\text { green areas by category }(\mathrm{m})\end{array}$} \\
\hline & & $\begin{array}{l}\text { 1. }<5 \\
\text { ha }\end{array}$ & $\begin{array}{l}\text { 2. } 5-50 \\
\text { ha }\end{array}$ & $\begin{array}{l}\text { 3. 50-100 } \\
\text { ha }\end{array}$ & $\begin{array}{l}\text { 4. }>100 \\
\text { ha }\end{array}$ \\
\hline Jordanovac - Dobri dol & G14 & 100 & Within & 800 & 1600 \\
\hline Dubrava - Dankovečka & G19 & 300 & 400 & 2100 & 1200 \\
\hline Črnomerec - Gjure Szaba & 19 & 40 & 1100 & 400 & 850 \\
\hline Trg bana Jelačića - Katedrala & 113 & 330 & Within & 500 & 1500 \\
\hline Voltino - Dragutina Golika & $J 9$ & Within & 550 & 3300 & 2300 \\
\hline Remiza - Jablanovečka ulica & $J 10$ & 650 & 1300 & 3900 & 2800 \\
\hline Trešnjevka - Cibonin toranj & $\mathrm{J} 12$ & 160 & 750 & 2600 & 2100 \\
\hline Marulićev trg & $J 12$ & Within & 100 & 3000 & 2500 \\
\hline Ferenšćica & J16 & Within & 700 & 1200 & 2600 \\
\hline Prečko - Paljetkova ulica & K6 & Within & 380 & 670 & 100 \\
\hline Srednjaci & K10 & 320 & Within & 650 & 1500 \\
\hline Knežija - Vjesnik & K11 & 140 & 300 & 1400 & 900 \\
\hline Vrbik - Prisavlje & K12 & 530 & Within & 660 & 170 \\
\hline Zeleni trg & K12 & 100 & Within & 1400 & 950 \\
\hline Most Slobode & K13 & 390 & 440 & 140 & Within \\
\hline Trnje - Lastovska & K14 & 100 & 200 & 2200 & 850 \\
\hline Knežija - Horvaćanska & L10 & 170 & 430 & 1800 & 500 \\
\hline Travno - Božidara Magovca & M14 & 80 & Within & 450 & 2200 \\
\hline \multicolumn{2}{|l|}{ Average distance $(\mathrm{m})$} & 190 & 370 & 1500 & 1300 \\
\hline
\end{tabular}




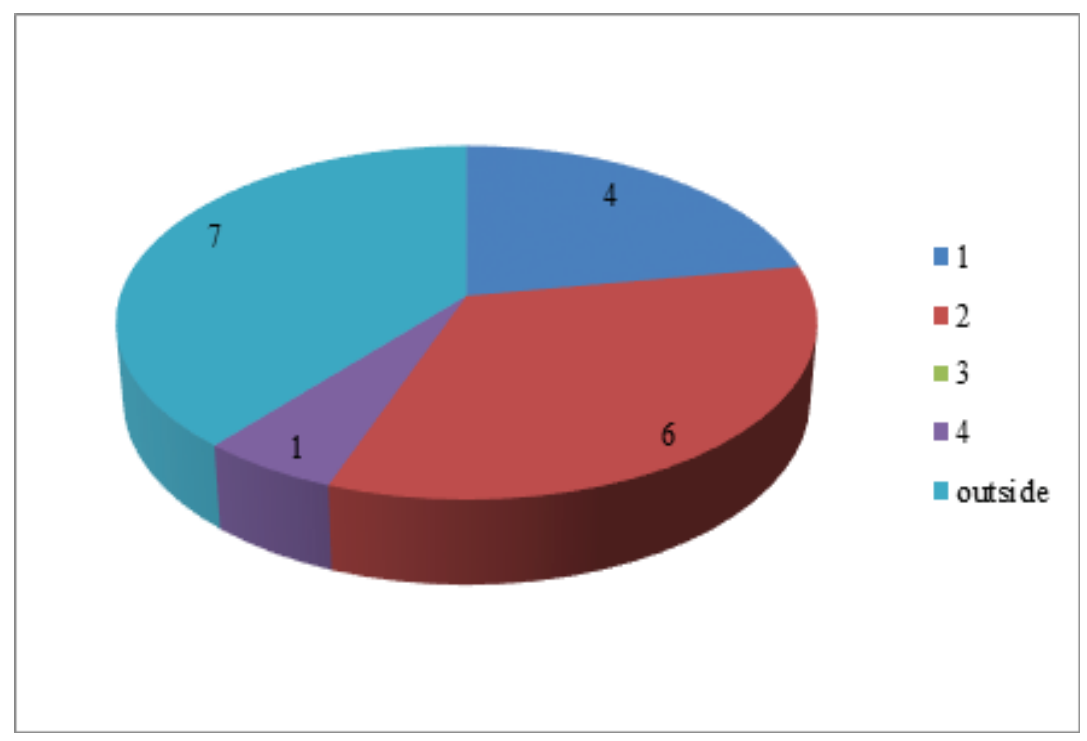

Figure 2. Numbers of nests within a certain category (1-4) of green areas.

Slika 2. Prikaz broja gnijezda unutar određene kategorije (1-4) zelenih površina.

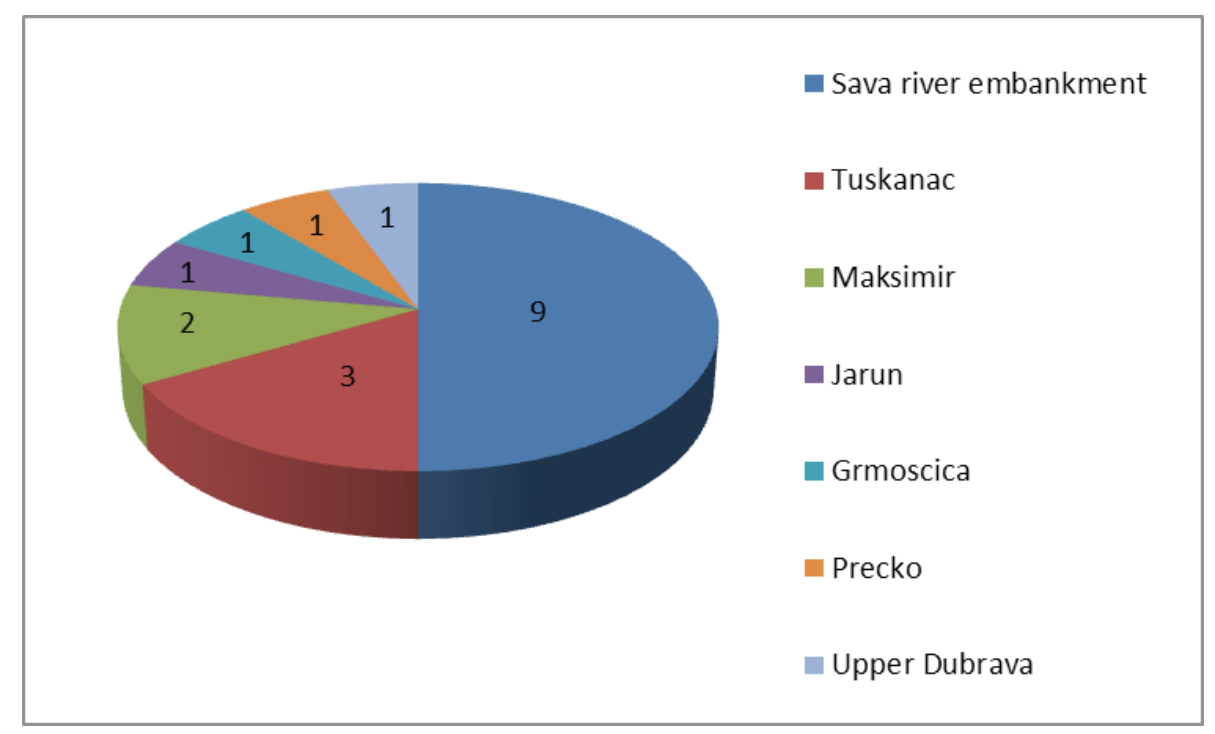

Figure 3. Distribution of the nests by the nearest surface belonging to category 4 . Slika 3. Distribucija broja gnijezda prema najbližoj površini 4. kategorije. 


\section{DISCUSSION}

The nesting of Common Kestrel in 2017 was recorded on a total of 13 atlas squares. Since this figure also includes the additional 3 squares, in 2017 nesting was confirmed on only 10 out of 28 initially analysed squares. Although this research does not exclude the possibility of Kestrels nesting within some other squares, it should be noted that data from the Atlas, on which this research was based, were up to 14 years old. Over the past period, there have been many changes within the city, both in the construction of new buildings and in the loss of old ones, but also in the creations of new green areas. The unsustainability of some nests is likely to be largely caused not only by human disturbance, but also by abandoning nests due to new and more favourable nesting sites. The study taken in Israel (CHARTER et al. 2007) showed that human disturbance caused $41 \%$ of all nesting failures of Kestrels, while $14 \%$ of the nests were abandoned. Besides human disturbance, the increasing population of urban House Crow Corvus corone cornix in Zagreb may also cause breeding failures in Kestrels or abandonment of nesting sites. Although this research has not shown nesting on many of the locations listed in the Atlas, this does not necessarily indicate a significant decline in Kestrel populations in Zagreb. Research in Berlin (KüBLER et al. 2005) has shown that Kestrel populations have been self-sustaining and stable over the years despite annual fluctuations up to $30 \%$.

The results have shown that the largest share (72\%) of nests was found on residential buildings. Three nests were placed on a business building (only one of them was active in 2017), one on the church tower and, one on a lightning pole. It can be concluded that residential buildings in Zagreb suit best as a nesting site for Kestrels. This has also been confirmed by the fact that the only currently active nest located in a business building in Zagreb is actually located in a historical building, which does not look like modern business buildings. The research in Rome (SALvATI et al. 1999) has also confirmed that Kestrels were usually choosing residential buildings for nesting in urban and rural areas, while avoiding old nests of crows and holes in the trees, probably due to shorter durability and lower protection compared to nesting on buildings. Unlike business skyscrapers, residential buildings are characterized by multiple openings, windows, windowsills and balconies. The great importance of old historic buildings for the nesting of Kestrels has further been confirmed in Vienna (Sumasgutner et al. 2014). Research in Israel (CHARTER et al. 2007) has shown that the majority of Kestrels in urban areas are nesting in flowerpots on windowsills. There was a similar situation in Budapest in 2006: 25 nests were recorded on windows, 11 in holes on walls, 3 on sculptures, 2 on cranes (in service), 1 on an airplane (out of service), 1 in a pigeon nest on the roof, and 1 in a crow's nest on a tree (Morandini 2008). On the other hand, researches in Vienna (Sumasgutner et al. 2014) and in Berlin (KüBler et al. 2005) have pointed out the 
importance of nest-boxes. While in Berlin most pairs are already nesting in nestboxes, in Vienna it is pointed to a growing importance of setting up nest-boxes due to widespread renovations of buildings. Furthermore, there were some examples in Budapest (Morandini 2010) where the owners of the buildings did not want to keep old nests during renovations, but most frequently there are cases where owners are helpful in keeping the nests and even enforce them after renovations.

Our research has shown that Kestrels choose buildings between 25 and $70 \mathrm{~m}$ high and mostly, but not exclusively, the highest buildings available, as $61 \%$ of the nests are located on the highest buildings in a range of $500 \mathrm{~m}$.

The analysis of the distances of nests from urban green areas has shown that Kestrel nests were closer to smaller green areas than to larger ones. This might be explained by the fact that there are more small green areas in the centre of the city, while larger green areas are mostly located in the city surroundings. The research in Vienna (SumasgutNer et al. 2014) has shown that Kestrel nests are located in areas characterized by high density of buildings, a greater number of green yards and greater distances to open green areas, as it is in Zagreb. The same research has also shown that nesting in the immediate vicinity to the green yards is related to earlier periods of laying eggs, higher hatching rates and larger fledged brood sizes, but these values are still lower than outside the city. Kestrels nesting in the city centre with a higher density of buildings have got more nesting possibilities, but less green areas needed for hunting. The importance of smaller green areas in Zagreb is shown by the fact that $55 \%$ (10) of the nests were situated within smaller green areas, while $38 \%$ (7) of the nests that were not located within green areas were between 40 and $650 \mathrm{~m}$ away from the nearest green area, which was usually category 1 area.

Despite the vicinity of a large number of smaller green areas, major importance for successful nesting of Kestrels is the possibility of hunting, i.e. the distance to open green areas outside the city centre. The research in the Czech Republic (RIEGERT et al. 2007), where Kestrels were tracked by using transmitters and wing tags, has shown that in urban Kestrels, the size of the hunting area varies from 0.8 to 25 square $\mathrm{km}$, and that male Kestrels spend a lot of energy while flying from unfavourable nesting locations in city centres to suitable hunting grounds. Due to the fact that similar research has not been conducted in Zagreb, it cannot be confirmed how often some of the analysed green areas are used for hunting. Without research that would include some of the bird tracking methods, we can only assume the importance of analysed green areas according to the data taken by observing Kestrel hunting activity during this period.

The centre of the city may be characterized by lower diversity in Kestrels' prey. The research in Berlin (KüBLER et al. 2005) has showed a lower variety in Kestrels' prey in the centre of the city compared to areas far from the centre; therefore, the distances between the nests and open green areas are of great importance. 
The long green embankment of the river Sava stretching through the city was shown to be the most important great green area in Zagreb, representing the nearest category 4 area for $50 \%$ of the nests. Besides the embankment of the Sava river, urban park Tuskanac was also of great importance being the nearest large green area to the city centre.

The nesting of Kestrels has been recorded in several Croatian cities, especially on high buildings such as church towers (Micevski 1989, RuCner 1998, Vidović 2006). However, this is the first study of habitat selection of the urban population of Kestrels in Croatia. It has been shown that the most suitable buildings for nesting of Kestrels in Zagreb are residential buildings with an average height of 50.1 meters. Both small and large urban green areas are important for hunting. Since many previously active nests were recently uninhabited, it is recommended to conduct monitoring of urban Kestrels in order to be able to identify the trend of this population.

\section{References}

Accu Weather (2017): https://www.accuweather.com/hr/hr/zagreb/117910/month/117910? monyr=3/01/2017 (access on December 8th 2017)

Chace J. F., WALsh J. J. (2004): Urban effects on native avifauna: a review. Landscape and Urban Planning.

Charter M., Izhaki I., Bouskila A., Leshem Y. (2007): Breeding success of the Eurasian Kestrel (Falco tinnunculus) nesting on buildings in Israel. J. Raptor Res. 41:139-143.

City of Zagreb, Official website (2017) http://www.zagreb.hr/popis-stanovnistva-kucanstava-i-stanova/1043 (access on December 8th 2017)

Department of applied computing, Official website (2017): http://web.zpr.fer.hr/ergonomija/2004/hendija/geografski.htm (access on December 8th 2017)

Jокімёкі J., Suhonen J., Kaisanlahti-Jокімёкі M.-L. (2016): Urbanization and species occupancy frequency distribution patterns in core zone areas of European towns. Eur. J. Ecol. 2: 23-43.

Kralj J., Barišıć S., Tutiš V., Ćiković D. (2013): Atlas selidbe ptica Hrvatske. Hrvatska akademija znanosti i umjetnosti, Zavod za ornitologiju, Zagreb.

Kralj, J., Krnjeta, D. (2015): Atlas ptica gnjezdarica grada Zagreba. Hrvatska agencija za okoliš i prirodu, Zagreb.

Kübler S., Kupko S., Zeller U. (2005): The kestrel (Falco tinnunculus L.) in Berlin: investigation of breeding biology and feeding ecology. J. Ornithol. 146: 271-278.

Micevski B. (1989): Ptice Đakova. Larus 40:137-146.

Morandini P. (2008): Budapesti vörös vércse költések. Heliaca 2006: 85-87.

Morandini P. (2010): Budapesti vörös vércse (Falco tinnunculus) költések - 2007-2008. Heliaca 2008: 77-81.

QGIS Development Team (2017): QGIS Geographic Information System. Open Source Geospatial Foundation Project. 
Riegert J., Fainová D., Mikeš V., Fuchs R. (2007): How urban Kestrels Falco tinnunculus divide their hunting grounds: partitioning or cohabitation? Acta Ornithol. 42: 69-76.

Rucner D. (1998): Ptice hrvatske obale Jadrana. Hrvatski prirodoslovni muzej, Zagreb.

Salvati L., Manganaro A., Fattorini S., Piattella E. (1999): Population features of Kestrels Falco tinnunculus in urban, suburban and rural areas in Central Italy. Acta Ornithol. 34: 53-58.

Sumasgutner P., Schulzec C. H., Krenn H. W., Gamauf A. (2014): Conservation related conflicts in nest-site selection of the Eurasian Kestrel (Falco tinnunculus) and the distribution of its avian prey. Landscape Urban Plan. 127: 94-103.

Sorace A. (2001): High density of bird and pest species in urban habitats and the role of predator abundance. Ornis Fennica 79:60-71.

Vidović S. (2006): Ptice na području grada Osijeka. Muzej Slavonije, Osijek.

Village A. (1990): The Kestrel: Introduction. T\&AD Poyser Ltd, London.

\section{SAŽETAK}

Urbanizirana područja sve se više šire te uništavajući prirodna staništa utječu na smanjenje raznolikosti životinjskih vrsta, a u manjoj mjeri stvaraju i nova staništa za određene vrste. Povećanje urbanizacije obično dovodi do povećanja biomase ptica ali i do smanjenja raznolikosti vrsta. Za ptice grabljivice urbana staništa mogu biti od vrhunske kvalitete, jer su u takvim staništima grabljivice često zaštićene od progona te mogu imati i zadovoljavajuću opskrbu hranom što im omogućava nastanjivanje inače neprikladnih ili neproduktivnih mjesta za gniježđenje. Među europskim grabljivicama, vjetruša (Falco tinnunculus) najuspješnije zauzima urbana područja što pokazuje viša stopa razmnožavanja kod urbanih populacija u usporedbi sa populacijama poljoprivrednih zemljišta. Vjetruša je jedna od najčešćih malih grabljivica u Europi koja, u usporedbi sa ostalim vrstama grabljivica, najuspješnije zauzima urbana područja. Stanarica je u gradu Zagrebu, prisutna je u gradu kroz cijelu godinu, te se gnijezdi i u samom centru grada. Cilj ovoga rada bio je najprije locirati a zatim i analizirati položaj trenutno aktivnih gnijezda vjetruša na području grada Zagreba u sezoni gniježđenja 2017. godine. Kao osnova poznavanja rasprostranjenosti vjetruše u Zagrebu poslužio je Atlas ptica gnjezdarica grada Zagreba. Nakon provedenog terenskog istraživanja, analizirane su značajke gnjezdišta, te su pomoću GIS programa izračunate udaljenosti analiziranih gnijezda do najbližih gradskih zelenih površina koje vjetruše koriste za lov i prehranu. Ovo istraživanje dalo je uvid u izbor staništa za gniježđenje vjetruša u Zagrebu. Rezultati su pokazali da je vjetrušama od najveće važnosti pri odabiru staništa tip građevine na kojima se gnijezdi te udaljenosti gnijezda do zelenih površina unutar i izvan centra grada. Stambene zgrade pokazale su se kao najpogodniji tip građevina za gniježđenje vjetruša, a visine građevina u većini slučajeva iznose između 25 i 70 metara (prosječno 50,1 26,1 metara) visine. Također je dokazano i to da vjetruše većinom biraju najviše dostupne građevine. Važnu ulogu pri odabiru staništa unutar centra grada predstavljaju manje zelene površine unutar kojih se nalazi većina analiziranih gnijezda, no od velike važnosti zbog mogućnosti lova predstavljaju i velike zelene površine udaljenije od samog centra grada. 